\title{
Toxic effect of cadmium adsorbed by different sizes of nano-hydroxyapatite on the growth of rice seedlings
}

\author{
Yifan Huang ${ }^{\mathrm{a}}$, Weiwen Qiu ${ }^{\mathrm{b}}$, Zhihong $\mathrm{Yu}^{\mathrm{a}}$, Zhengguo Song ${ }^{\mathrm{a}, *}$ \\ a Agro-environmental Protection Institute, Ministry of Agriculture, Key Laboratory of Production Environment Quality, Ministry of Agriculture of China, \\ Tianjin, 300191, China \\ b The New Zealand Institute for Plant and Food Research Limited, Private Bag 4704, Christchurch, 8140, New Zealand
}

\section{A R T I C L E I N F O}

Article history:

Received 16 December 2016

Received in revised form 3 March 2017

Accepted 5 March 2017

Available online 14 March 2017

\section{Keywords:}

Nanoparticle

Hydroxyapatite-adsorbed $\mathrm{Cd}^{2+}$

Toxicity

Rice seedling

\begin{abstract}
A B S T R A C T
Information regarding the toxic effects of cadmium (Cd) adsorbed by nano-hydroxyapatite (NHAP-Cd) on the growth of crop plants remain limited. We investigated the mechanism of NHAP-Cd (diameters, 20 and $40 \mathrm{~nm}$; $\mathrm{NHAP}_{20}-\mathrm{Cd}$ and $\mathrm{NHAP}_{40}-\mathrm{Cd}$, respectively) phytotoxicity. Rice seedlings treated with $\mathrm{Cd}$ and $\mathrm{NHAP}_{20}-\mathrm{Cd}$ showed more severe growth retardation compared to those treated with $\mathrm{NHAP}_{40}{ }^{-}$ $\mathrm{Cd}$, for the same Cd concentration. Transmission electron microscopy revealed NHAP in the seedlings. The nanoparticles entered the rice seedlings with no $\mathrm{Cd}^{2+}$ signals in the NHAP treatments compared to $-0.47 \mathrm{pmol} \mathrm{cm}^{-2} \mathrm{~s}^{-1}$ of $\mathrm{Cd}^{2+}$ fluxes in the $\mathrm{Cd}$ treatment. The higher $\mathrm{Cd}^{2+}$ content in the leaves and mesocotyl of $\mathrm{NHAP}_{20}-\mathrm{Cd}$-treated rice seedlings suggested that smaller NHAP-Cd can translocate easily to the aboveground parts. Further, NHAP-Cd increased oxidative stress, which was determined as catalase activity changes in this study. Thus, NHAP-Cd particles in the growth medium can be transported to rice seedlings and cause toxicity.
\end{abstract}

(c) 2017 Elsevier B.V. All rights reserved.

\section{Introduction}

Cadmium (Cd) is a ubiquitous heavy metal pollutant in the ecosystem. It is extensively used in batteries and pigment industry and adversely influences food safety in China (Bian et al., 2013). Thus, it has received considerable attention. Intensive studies on the toxicology of $\mathrm{Cd}^{2+}$ have revealed that nano-adsorbents can be used to control Cd contamination (Zhang et al., 2010). However, the increased application of nanoparticles (NPs) led to their inevitable introduction into the environment. Hence, concerns regarding their potential adverse effects on the soil and water ecosystems are increasing (Roh et al., 2009; Shah and Belozerova, 2009).

NPs can be adsorbed onto plant surfaces and are taken up by plant openings having a size of nano- or micrometers, such as the stomata, stigma, and hydathodes, or via some other natural pathways (Dietz and Herth, 2011). Some studies have investigated the impact of NPs on plants and indicated that plant species and NP characteristics (size, chemical composition, and surface functionality) influence the uptake, transport, and toxicity of NPs (Barrena

Abbreviations: HMI, heavy metal ion; NHAP, nano-hydroxyapatite; NHAP-Cd, nano-hydroxyapatite-adsorbed $\mathrm{Cd}^{2+}$; DEDSs, Dot-like electron dense structures.

* Corresponding author.

E-mail address: forestman1218@163.com (Z. Song). et al., 2009; Lee et al., 2008). However, the NP size-related toxicity enhancement has not yet been completely investigated. Dispersible NPs of some materials have been reported to enter plants as intact particles $\left(\mathrm{ZnO}, \mathrm{Cu}, \mathrm{Ag}, \mathrm{Al}_{2} \mathrm{O}_{3}\right.$, and $\left.\mathrm{Fe}_{3} \mathrm{O}_{4}\right)$, whereas NPs of other materials gradually release ions that subsequently enter the plants (e.g., $\mathrm{Ag}^{+}, \mathrm{Al}^{3+}, \mathrm{Zn}^{2+}, \mathrm{Cu}^{2+}$; Gaiser et al., 2009; Katsnelson et al., 2011; Lin et al., 2009a,b; Midander et al., 2009; Wang et al., 2009). The most well-accepted mechanism of in vivo nanotoxicity involves the generation of oxidative stress (Stone and Donaldson, 2006), resulting in genetic toxicity (Rezvanfar et al., 2013) and apoptosis.

In recent years, the risk of heavy metal ions (HMIs) depositing onto nano-adsorbents was increased by the artificial release of NPs, leading to the formation of NP-HMI complexes that might be toxic in a different way than single NPs. For example, cerium oxide and nano-sized titanium dioxide were shown to significantly increase the toxicity of $\mathrm{Pb}^{2+}$ in Ceriodaphnia dubia (Wang et al., 2011), implying that NPs enhanced the toxicity of lead ions. Few studies suggested that NPs carrying HMIs can be toxic to organisms via the combined or individual effects of these toxic substances. At the cellular level, Cd ions or other HMIs are known to mainly remain in the cytoderm (Nie et al., 2014; Zeng et al., 2011), and their translocation beyond the cytoderm is blocked. HMIs can be enriched by nanoadsorbents, for example, $\mathrm{N}$-2-pyridylsuccinamic acid fractionalised halloysite nanotubes can enrich $\mathrm{Pb}^{2+}$ translocation (He et al., 2013), and some NPs have been shown to enrich toxicants (Usenko et al., 
2007). However, some studies have shown that NPs directly enter the cytoderm (Trujillo-Reyes et al., 2014). This implies that NPs, especially nano-adsorbents, can carry toxicants intracellularly and directly damage the organelles and nucleus. Further, NPs absorbed by plants can enter the cells and cause oxidative stress and DNA damage (Shaw and Hossain, 2013). Nano- $\mathrm{TiO}_{2}$ has been reported to enhance the toxicity of $\mathrm{Cu}^{2+}$ in Daphnia magna (Fan et al., 2011). NPs are presumed to transport toxicants to important organelles via diverse pathways, such as via the nucleus; however, large-sized NPs are difficult to pass through the cytoderm (Dietz and Herth, 2011). The data from different laboratory tests regarding the transport of NPs have yielded conflicting results (Harper et al., 2014); the mechanisms of uptake and translocation of NPs in plants have not yet been intensively investigated. Therefore, the overall biosafety of nano-adsorbents needs to be assessed.

As a water-stable and biocompatible nano-material (Huang and Wang, 2007), nano-hydroxyapatite (NHAP) is widely used for medicinal purposes (Rong et al., 2016). NHAP has been increasingly used as a nano-adsorbent to remediate $\mathrm{Cd}$ contamination in aqueous and soil environments owing to its remarkable adsorption capacity for HMIs (Jin et al., 2016; Wang et al., 2016). However, very little information is available regarding the toxicity of NHAP-Cd composites to crop plants. Therefore, this study aimed to confirm whether NHAP-Cd can enter rice seedlings through the cytoplasm; evaluate the toxicology of NHAP-Cd and its interactions with enzymes and other biomolecules in rice seedlings; investigate the size-related toxicity enhancement of NHAP-Cd; and determine the difference in toxic effects between $\mathrm{Cd}^{2+}$ and NHAP-Cd on rice seedlings.

\section{Materials and methods}

\subsection{Chemicals}

NHAP (20 and $40 \mathrm{~nm}$; 99.8\%) was purchased from Dekedaojin Co. (Beijing, China). All chemicals were purchased from Hengshan Co. (Tianjin, China). The $1000 \mathrm{mg} / \mathrm{L}$ atomic absorption spectrometry (AAS) standard solution of Cd or copper was obtained from Sigma-Aldrich (St. Louis, MO). Ultrapure water was further purified $(18 \mathrm{M} \Omega / \mathrm{cm})$ using a Millipore-Q water purification system.

\subsection{Plant material and stress conditions}

\subsubsection{Rice seedling preparation}

Seeds of rice (Oryza sativa L.) 'TU-705' were surface-sterilised with $0.5 \%$ sodium hypochlorite solution and imbibed in water for $48 \mathrm{~h}$. Seedlings were raised for 7 days in vermiculite cultures and saturated with Hoagland nutrient solution (Hoagland and Arnon, 1938). The rice seedlings were cultured in $1 / 2$ Hoagland nutrient solution in a growth chamber at $26^{\circ} \mathrm{C}, 60 \%$ relative humidity, and photoperiod of $18 \mathrm{~h}$ of light ( $4000 \mathrm{LX}$ ): $6 \mathrm{~h}$ of dark until the longest leaf was $15 \mathrm{~cm}$. Next, the rice seedlings were removed from the nutrient solution, and the roots were carefully washed with distilled water to remove the nutrient solution from the root surface.

\subsubsection{Preparation of NHAP-Cd suspension}

First, $0.05 \mathrm{~g}$ of 20 and $40 \mathrm{~nm}$ NHAP was suspended in water and treated with ultrasonic waves ( $1 \mathrm{KW}, 30 \mathrm{~min})$. The $C d$ concentration was adjusted to $0,1,2,5$, and $10 \mathrm{mg} / \mathrm{L}$ (the concentration gradient was determined as reported previously for the same variety of rice) by adding $1000 \mathrm{mg} / \mathrm{L} \mathrm{Cd}^{2+}$ solution. Considering that NHAP has greater adsorption ability (Feng et al., 2010), sufficient amount of NHAP was used to adsorb $\mathrm{Cd}$ in the solution so that no $\mathrm{Cd}^{2+}$ remained in the suspension.

The rice seedlings were cultured either with distilled water containing $\mathrm{Cd}^{2+}$ at a concentration of $0,1,2,5$, and $10 \mathrm{mg} / \mathrm{L}$ as control or in combination with NPs (200 $\mathrm{mg} / \mathrm{L}$ of $20 \mathrm{~nm}$ or $40 \mathrm{~nm} \mathrm{NHAP)}$. Three treatments were performed for each concentration of $\mathrm{Cd}^{2+}$ addition, i.e., $\mathrm{CK}$ (control treatment), $\mathrm{NHAP}_{20}-\mathrm{Cd}$, and $\mathrm{NHAP}_{40}-\mathrm{Cd}$ treatment. Each treatment was replicated three times, and every replicate had three rice seedlings. The rice seedlings were cultured for 7 days before harvest. Seedlings were maintained in a greenhouse for 10 days at $25^{\circ} \mathrm{C}$ under $16 \mathrm{~h}$ light $/ 8 \mathrm{~h}$ dark condition. The rice seedlings were cultured for 7 days before harvest. The seedlings were uprooted, and the roots, mesocotyl, and leaves were separated and used for analysis.

\subsection{Transmission electron microscopy}

Root sections were obtained from fresh rice seedlings, and their edges were lopped off. The sections were washed with phosphate buffered saline (PBS) and dried using an air pump at an appropriate pressure. Subsequently, the tissues were rapidly fixed with $3 \%$ glutaraldehyde and stacked upside down. The fixative was then gradually replaced with $0.1 \mathrm{M} \mathrm{PBS}(\mathrm{pH}=7.2)$ by replacing the buffer every $30 \mathrm{~min}$ for $3 \mathrm{~h}$. The tissues were then post-fixed with $1.0 \%$ osmium tetroxide (prepared using PBS), dehydrated through a volume fraction series of ethanol from $10 \%$ to $100 \%$, transferred to isoamyl acetate solution, and infiltrated with spurring epoxy resin overnight before obtaining $80-\mathrm{nm}$ thin sections by using an ultramicrotome (EM UC 7; Leica, Germany). The tissues and cells were observed using transmission electron microscopy.

\subsection{Evaluation of physiological parameters}

\subsubsection{Determination of seedling growth}

Growth of rice seedlings in terms of fresh weight and root parameters were measured at 7 days. They were then divided into three parts: aboveground, mesocotyl, and roots.

\subsubsection{Determination of $C d$ content}

The seedlings roots were washed with $20 \mathrm{mmol} / \mathrm{L}$ EDTA-2Na solution to remove the adsorbed Cd on the surface. Next, they were rinsed with deionized water and dried at $65^{\circ} \mathrm{C}$ to a constant weight for biomass and Cd content analysis. Subsequently, $0.25 \mathrm{~g}$ samples were ground and digested in $7 \mathrm{~mL} \mathrm{HNO}_{3}$ at $115^{\circ} \mathrm{C}$, followed by dissolving in $2 \mathrm{~mL}$ hydrogen peroxide (GR, 30\%), which led to the release of bound $\mathrm{Cd}^{2+}$ in the ionic form in the solution. The solution was allowed to stand for $5 \mathrm{~h}$ and then heated at $110^{\circ} \mathrm{C}$. The $\mathrm{Cd}^{2+}$ content was then measured using AAS (Analytikjena; Zeenet 700) and expressed in $\mathrm{mg} / \mathrm{g}$ fresh weight. A standard sample was run between every 10 samples. The recovery percentages were $97.5 \%-101.5 \%$, and the relative standard deviation of the determination was less than $2.6 \%$.

\subsection{Enzyme preparation and assays}

\subsubsection{Preparation of enzyme extract}

All solutions and containers used in the enzyme extraction process were pre-cooled. Fresh leaf tissue samples $(0.5 \mathrm{~g})$ were placed in centrifuge tubes containing PBS solution with the extractant (0.292 $\mathrm{g}$ EDTA-2Na dissolved in $1 \mathrm{~L}$ PBS, $\mathrm{pH}=7.0)$ and polyvinylpyrrolidone (PVP-30); the tubes were then centrifuged at $4{ }^{\circ} \mathrm{C}$ at $10,000 \mathrm{rpm}$ for $10 \mathrm{~min}$. The supernatant was used for analysing of catalase (CAT) activity.

\subsubsection{CAT assay}

Catalase (CAT, EC 1.11.1.6) activity was assayed by measuring the rate of disappearance of hydrogen peroxide as reported by Maehly and Chance (1959). The reaction mixture contained $2.5 \mathrm{~mL}$ of $50 \mathrm{mM}$ phosphate buffer $(\mathrm{pH}=7.4), 0.1 \mathrm{~mL}$ of $1 \%$ hydrogen peroxide, and $50 \mathrm{~mL}$ enzyme extract diluted to ensure that 


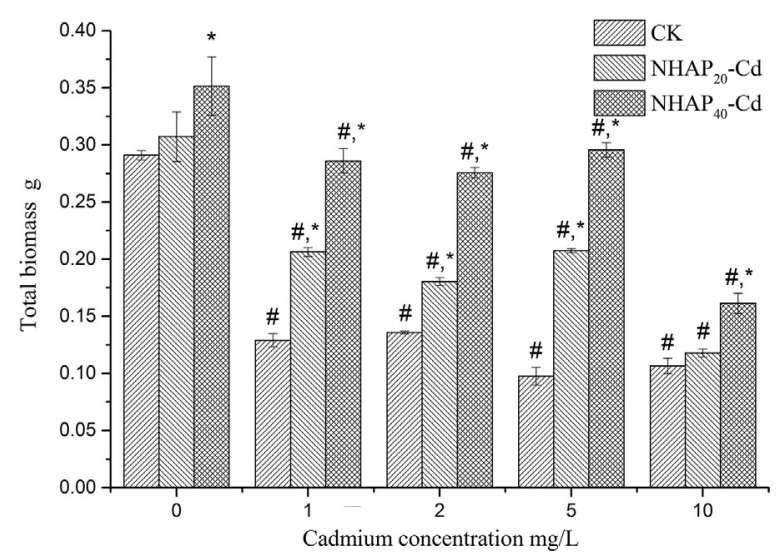

Fig. 1. Biomass of rice seedlings of $\mathrm{Cd}, \mathrm{NHAP}_{20}-\mathrm{Cd}$ and $\mathrm{NHAP}_{40}-\mathrm{Cd}$ treatments. \# The significant difference in each treatment at different $\mathrm{Cd}$ concentration *The significant difference between $\mathrm{CK}, \mathrm{NHAP}_{20}-\mathrm{Cd}$ and $\mathrm{NHAP}_{40}-\mathrm{Cd}$ treatments at same cadmium concentration (Kruskal-Wallis, $P<0.05$ ).

the measurements were within the linear range of the analysis. The decrease in hydrogen peroxide was followed as a decline in absorbance at $240 \mathrm{~nm}$.

\section{6. $\mathrm{Cd}^{2+}$ flux measurement}

In all, 7 days were required to detect the $\mathrm{Cd}^{2+}$ flux by using untreated rice seedlings. Non-invasive microelectrode (NIMT) detection was performed to determine the spatial characteristics and real-time kinetics of $\mathrm{Cd}^{2+}$ transport on the surface of root hair. The $\mathrm{Cd}^{2+}$ signal can be an evidence for the existence of $\mathrm{Cd}^{2+}$ on the surface of the outer root hair, which indicated whether $\mathrm{Cd}$ was translocated into the rice seedlings in the ionic form. If $\mathrm{Cd}^{2+}$ was strongly contacted on the NPs, there would be no $\mathrm{Cd}^{2+}$ signal, which can help in confirming whetherif $\mathrm{Cd}$ had been translocated into the rice seedlings. Details on the fabrication and calibration of $\mathrm{Cd}^{2+}$ selective microelectrodes have previously been described (Li et al., 2012). Briefly, the primary root of an intact plant was mounted horizontally in the measuring chamber and loosely fixed in place with dental wax. A part of the rice seedling roots with root hair was cut. Three detection sites that were $200 \mu \mathrm{m}$ apart were set on the root. The flux data were obtained using the ASET software, which is a part of the SIET system. The raw data from all measurements, including the estimation of background concentration $(\mathrm{mV})$ and difference in local gradients $(\mathrm{mV})$, were converted to net $\mathrm{Cd}$ fluxes (pmol cm ${ }^{-2} \mathrm{~s}^{-1}$ ) by using Mage Flux (http://xuyue.net/mageflux; Xu-Yue Company).

\subsection{Statistical analysis}

All statistical analyses were performed using SPSS 21.0 software (SPSS Inc., Chicago, IL). Kruskal-Wallis test was used to measure significant differences between treatments. A $P$ value of $<0.05$ indicated statistical significance.

\section{Results}

\subsection{Evaluation of growth and physiological parameters of rice seedlings exposed to $\mathrm{Cd}^{2+}$ and/or NHAP}

The biomass of seedlings of $\mathrm{CK}$ was less than that of seedlings in the NHAP treatments. The seedlings treated with $\mathrm{NHAP}_{40}-\mathrm{Cd}$ had the highest biomass (Fig. 1). Significant differences in biomass between the $\mathrm{CK}, \mathrm{NHAP}_{20}-\mathrm{Cd}$, and $\mathrm{NHAP}_{40}-\mathrm{Cd}$ treatments were subjected to the same concentration of $\mathrm{Cd}$ addition $(P<0.05)$. The

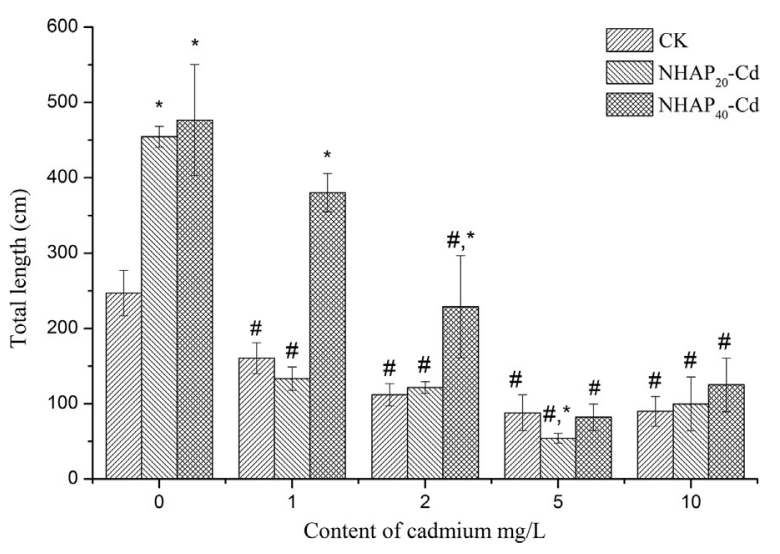

Fig. 2. Total length of rice seedlings root of $\mathrm{Cd}, \mathrm{NHAP}_{20}-\mathrm{Cd}$ and $\mathrm{NHAP}_{40}-\mathrm{Cd}$ treatments.

\# The significant difference in each treatment at different $\mathrm{Cd}$ concentration ${ }^{*}$ The significant difference between $\mathrm{CK}, \mathrm{NHAP}_{20}-\mathrm{Cd}$ and $\mathrm{NHAP}_{40}-\mathrm{Cd}$ treatments at same cadmium concentration (Kruskal-Wallis, $P<0.05$ ).

plants exposed to CK with $1 \mathrm{mg} / \mathrm{L}$ Cd stopped growing immediately, whereas continuous growth was noted for those treated with $\mathrm{NHAP}_{20}-\mathrm{Cd}$ and $\mathrm{NHAP}_{40}-\mathrm{Cd}$.

Rice seedlings treated with $\mathrm{NHAP}_{40}-\mathrm{Cd}$ showed the greatest root growth, followed by that in $\mathrm{NHAP}_{20}-\mathrm{Cd}$ treatment and $\mathrm{CK}$ (seedlings treated with $\mathrm{Cd}^{2+}$ ) until toxicity appeared (Fig. 2). The rice seedlings remained alive at a concentration of 1 or $2 \mathrm{mg} / \mathrm{L} \mathrm{Cd}$; with this concentration, the total root length in $\mathrm{NHAP}_{40}-\mathrm{Cd}$ treatment was longer than that in the $\mathrm{NHAP}_{20}$-Cd treatment, which suggests nanomaterials promote root growth. However, with an increase in $\mathrm{Cd}$ concentration, root elongation was inhibited; thus, the nanomaterials detoxified $\mathrm{Cd}$, but the detoxification efficiency of $\mathrm{NHAP}_{20}$ was less than that of $\mathrm{NHAP}_{40}$.

\subsection{Distribution of Cd and NPs in the rice seedlings}

The TEM images of rice seedlings incubated with a combination of $200 \mathrm{mg} / \mathrm{L}$ NHAP and $0,1,2,5$, and $10 \mathrm{mg} / \mathrm{L}$ Cd for 7 days showed the presence of NHAP in the roots. Dot-like electron-dense structures (DEDSs) were detected in the roots of seedlings that were exposed to NHAP-Cd (Fig. 3). Most of the DEDSs (diameter, about $50 \mathrm{~nm}$ ) were deposited near the cytoderm, implying that the NPs retained their nanostructure after they were transported into the seedling tissue (Fig. 3).

Whether Cd was completely loaded onto the surface of the NPs was determined by assessing the aqueous solution of each treatment. By using AAS, we detected $\mathrm{Cd}$ in the CK seedlings after the aqueous solution was filtered using a $0.22-\mu \mathrm{m}$ nylon prefilter membrane. As expected, Cd was not found in any of the NHAP treatments. Dynamic light scattering (DLS; Brookhaven BI-200SM) detection in aqueous solution showed that the $20 \mathrm{~nm}$ HAP was smaller than the $40 \mathrm{~nm}$ HAP in the aqueous form, but formed aggregates more readily. The deposition of NPs in the cells of rice seedlings is shown in Fig. 3. NHAP was found to pass through the cell membrane and enter the cytoderm.

The rice seedlings were separated into three parts: aboveground (leaves), mesocotyl, and roots. No significant difference was found in $\mathrm{Cd}$ absorption in the roots between $\mathrm{NHAP}_{20}-\mathrm{Cd}$ and $\mathrm{NHAP}_{40}-\mathrm{Cd}$ treatments (Fig. 4); however, significant reduction in Cd absorption was noted in both treatments compared to that in CK. Furthermore, $\mathrm{Cd}$ accumulation in the aboveground part and mesocotyl was significantly different between $\mathrm{NHAP}_{20}-\mathrm{Cd}$ and $\mathrm{NHAP}_{40}-\mathrm{Cd}$ treatments, with higher accumulation in the former than that in the latter. $\mathrm{Cd}$ accumulation for both $\mathrm{NHAP}_{20}-\mathrm{Cd}$ and $\mathrm{NHAP}_{40}-\mathrm{Cd}$ treatments was greater in the roots than in the aboveground parts and mesocotyl. 


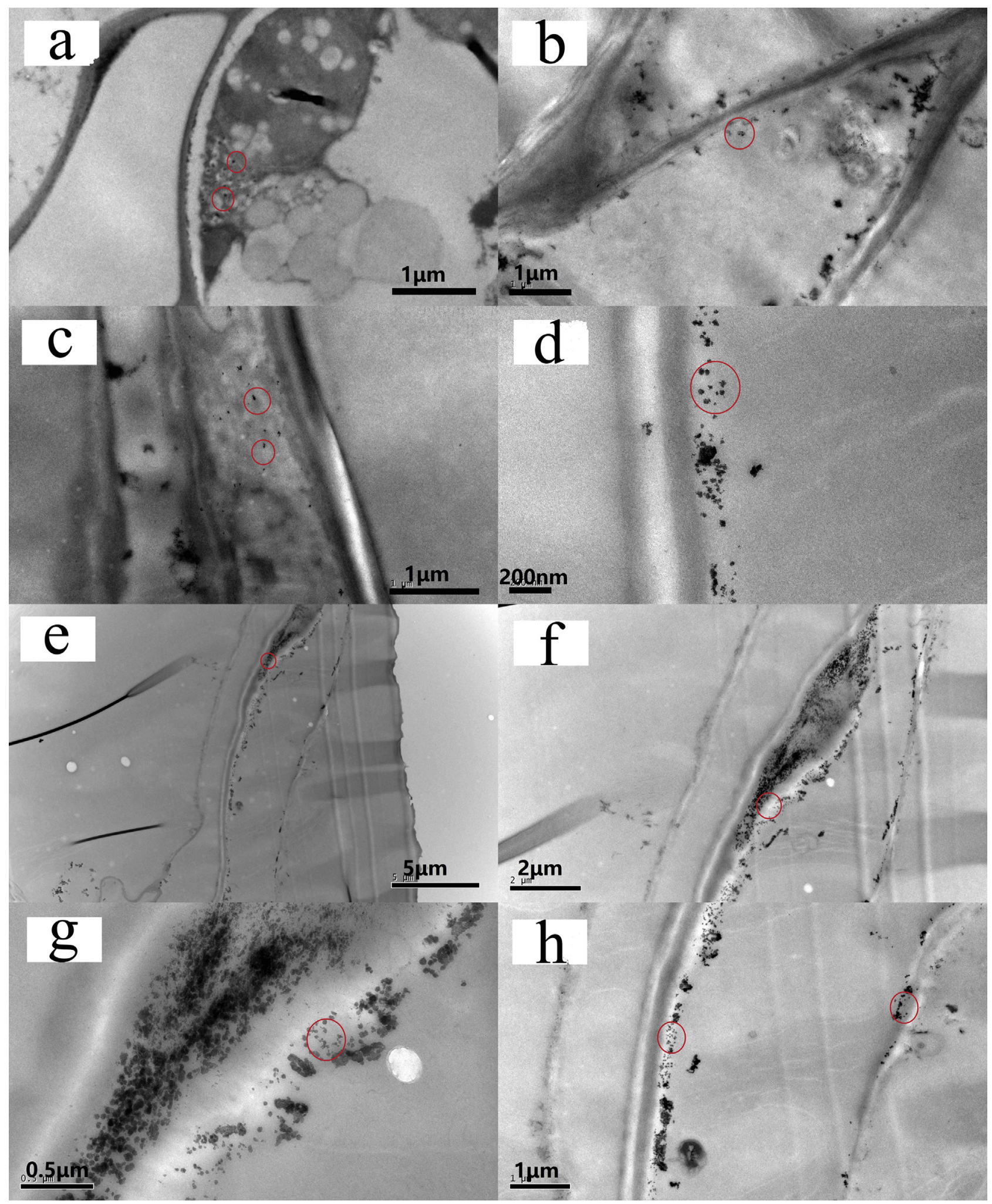

Fig. 3. TEM observations of rice seedlings roots with treated NHAP-Cd (a-h).

3.3. Current velocity across the cytoderm of $\mathrm{Cd}^{2+}$-treated seedlings

The mechanism of how NHAP-Cd passed through the cytoderm was determined and the $\mathrm{Cd}$ ion velocity around the root hair was detected by measuring $\mathrm{Cd}^{2+}$ fluxes by using NIMT; this allowed assessing whether Cd was translocated in the ionic form from the treatment solutions into the rice seedlings. $\mathrm{Cd}^{2+}$ fluxes in the roots were about $-0.47 \mathrm{pmol} \mathrm{cm}^{-2} \mathrm{~s}^{-1}$ when the seedlings were treated with $5 \mathrm{mg} / \mathrm{L} \mathrm{Cd}^{2+}$; this was considerably below the zero line. However, the $\mathrm{Cd}^{2+}$ fluxes in other treatments almost overlapped with level at $0 \mathrm{pmol} \mathrm{cm}^{-2} \mathrm{~s}^{-1}$. No $\mathrm{Cd}^{2+}$ signal was detected in the NHAP 

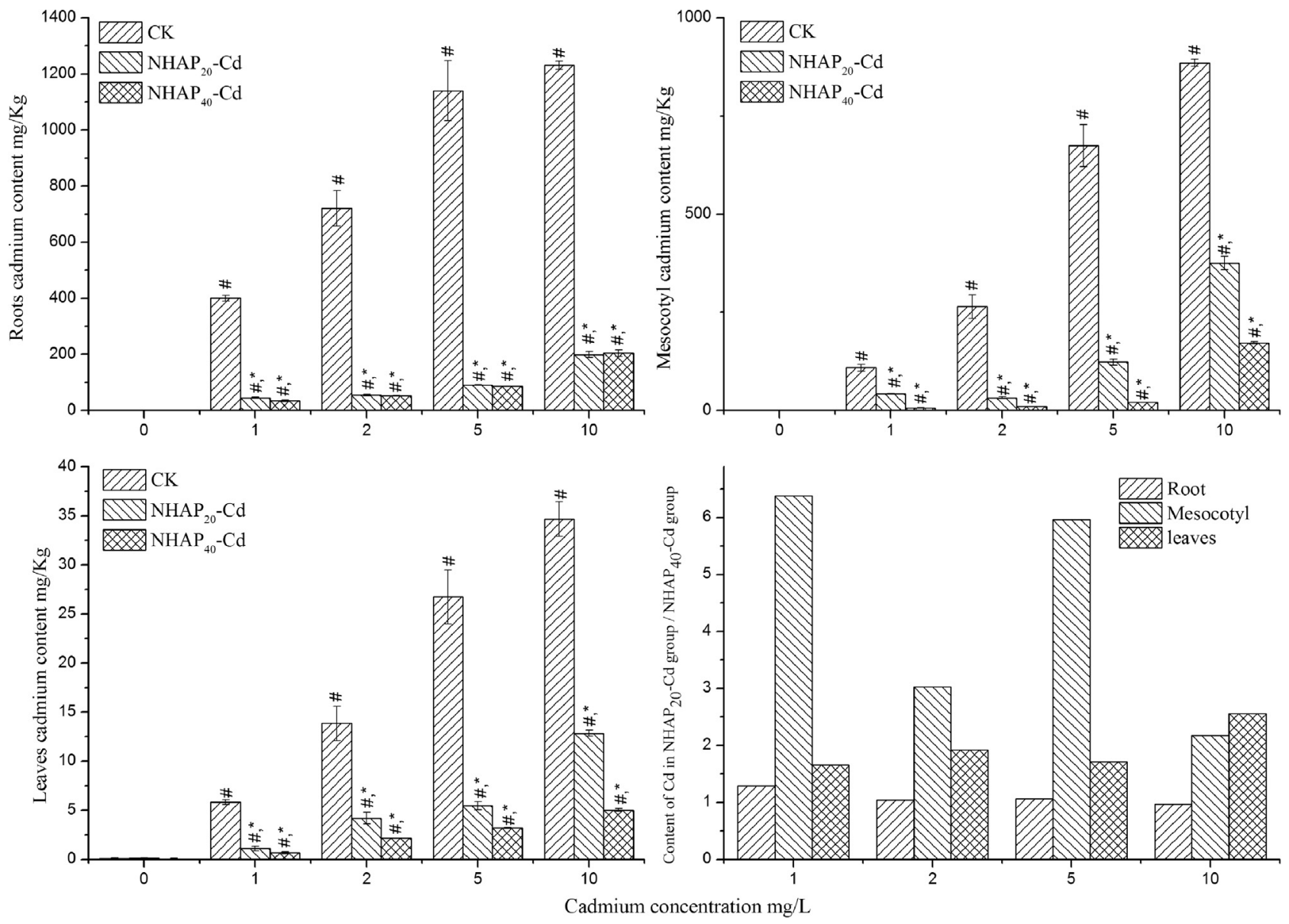

Fig. 4. The content of $\mathrm{Cd}$ in three parts (root, mesocotyl and aboveground) of rice seedlings among different treatments.

\# The significant difference in each treatment at different $\mathrm{Cd}$ concentration

*The significant difference between $\mathrm{CK}, \mathrm{NHAP}_{20}-\mathrm{Cd}$ and $\mathrm{NHAP}_{40}-\mathrm{Cd}$ treatments at same cadmium concentration (Kruskal-Wallis, $P<0.05$ ).

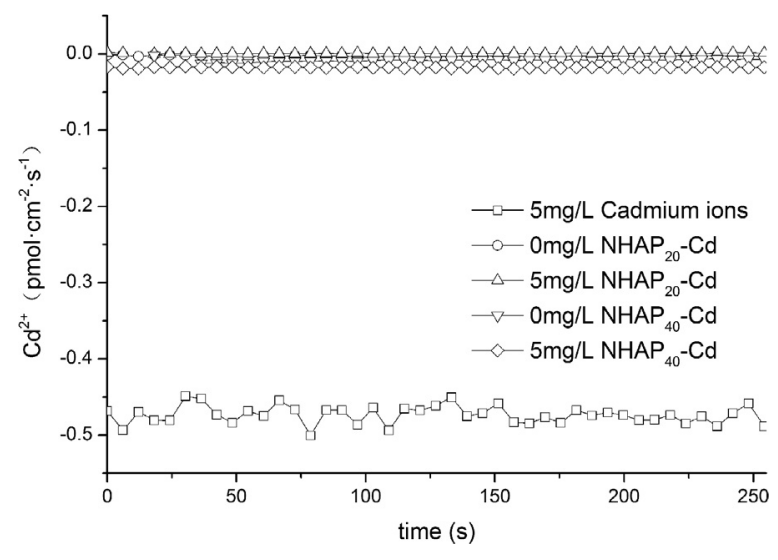

Fig. 5. $\mathrm{Cd}^{2+}$ fluxes in rice seedlings root among different treatments.

treatments (Fig. 5). However, $\mathrm{Cd}^{2+}$ signal was detected in the root hair of all treatments, suggesting that Cd could pass through the cell wall via a unique mechanism.

\subsection{Effect on antioxidant enzymes in rice seedlings}

In this study, CAT activity was found to increase for all treatments except for the $\mathrm{NHAP}_{40}-\mathrm{Cd}$ treatment for concentrations of $\mathrm{Cd}^{2+}$ ranging from 0 to $5 \mathrm{mg} / \mathrm{L}$ (Fig. 6). The CAT level was exhibited in the order of $\mathrm{CK}>\mathrm{NHAP}_{20}-\mathrm{Cd}>\mathrm{NHAP}_{40}-\mathrm{Cd}$ treatment at the

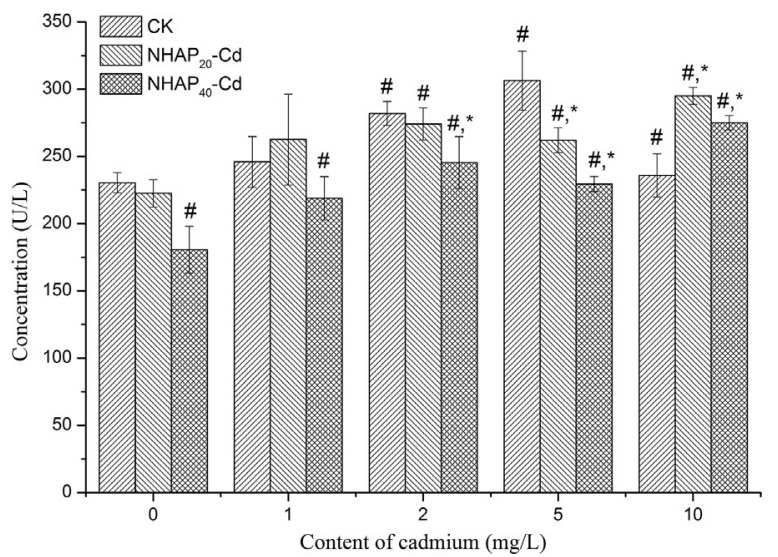

Fig. 6. CAT activity of rice seedlings leaves treated NHAP-Cd.

\# The significant difference in each treatment at different $\mathrm{Cd}$ concentration *The significant difference between $\mathrm{CK}, \mathrm{NHAP}_{20}-\mathrm{Cd}$ and $\mathrm{NHAP}_{40}-\mathrm{Cd}$ treatments at same cadmium concentration (Kruskal-Wallis, $P<0.05$ ).

Cd concentration of less than $10 \mathrm{mg} / \mathrm{L}$. The above findings indicated that high concentration of $\mathrm{Cd}$ caused serious oxidative stress. However, the enzyme activity at Cd concentration of $10 \mathrm{mg} / \mathrm{L}$ was considerably lower in $\mathrm{CK}$ than in the $\mathrm{NHAP}_{20}-\mathrm{Cd}$ and $\mathrm{NHAP}_{40}-\mathrm{Cd}$ treatments. Further studies are warranted to determine the reason for this finding. 


\section{Discussion}

The application of large amount of NHAP-Cd resulted in greater biomass of plants. At $5 \mathrm{mg} / \mathrm{L}$ of $\mathrm{Cd}$ concentration, $\mathrm{NHAP}_{40}-\mathrm{Cd}$ enhanced the biomass and total length of roots. This could be attributed to the fact that $\mathrm{NHAP}_{40}-\mathrm{Cd}$ decreased $\mathrm{Cd}$ toxicity that includes inhibition of photosynthesis, reduction of plant biomass, and restraint of root growth (Moya et al., 1993). Previous studies showed that NPs with a diameter of $5-8 \mathrm{~nm}$ can be readily transferred through the cell wall pores, and NPs smaller than $20 \mathrm{~nm}$ can move via plasmodesmata between plant cells. Thus, $\mathrm{NHAP}_{20}-\mathrm{Cd}$ was speculated to be easily translocated in the plant cells. Interestingly, a greater difference in $\mathrm{Cd}$ transport abilities of $\mathrm{NHAP}_{20}-\mathrm{Cd}$ or $\mathrm{NHAP}_{40}-\mathrm{Cd}$ between the aboveground part and mesocotyl was noted. Further, unlike larger NPs, $\mathrm{NHAP}_{20}-\mathrm{Cd}$ had a greater ability to pass through the mesocotyl and translocated to other parts. The $\mathrm{Cd}$ content in the mesocotyl was higher than that in the aboveground parts in all treatments. This difference could be attributed to the structural difference between the mesocotyl and the aboveground parts. The mesocotyl of rice seedlings has a developed vascular bundle, which is relatively similar to that in Avena sativa (Tateoka, 1969) since they belong to same species; because of this, NHAPCd experienced a diameter-related resistance from the mesocotyl. The accumulation of $\mathrm{Cd}$ suggested that the vascular bundle was the primary mode of NHAP-Cd translocation in rice seedlings.

The NIMT analysis was conducted to determine whether NPs can pass through the cytoderm without releasing HMIs by detecting the $\mathrm{Cd}$ ion velocity around the root hair. As expected, no $\mathrm{Cd}$ signal was detected in the NHAP-treated groups, whereas greater $\mathrm{Cd}$ ion inflow of $-0.47 \mathrm{pmol} \mathrm{cm} \mathrm{c} \mathrm{s}^{-1}$ was noted in the CK. Our finding is consistent with that of Mobasherpour et al. (2012). Since the combination of NHAP-Cd is toxic to rice seedlings, we assumed that the mechanism of NHAP-Cd toxicity to plants was different from that of either Cd ions (Shah et al., 2001) or NHAP (Bala et al., 2014). The NIMT test revealed different toxicity levels between NHAP-Cd and $\mathrm{Cd}^{2+}$. The analysis also showed that no $\mathrm{Cd}^{2+}$ remained in the solution after its combination with NAHP. Further studies are warranted to determine how NHAP-Cd caused toxicity to rice seedlings by investigating the intracellular behaviour of NHAP-Cd. The NIMT study also revealed that no $\mathrm{Cd}$ ions were released when $\mathrm{NHAP}_{20}-\mathrm{Cd}$ or $\mathrm{NHAP}_{40}-\mathrm{Cd}$ was transported into the plants; the oxidative stress level of NHAP-Cd treatments was higher than that of CK when the $\mathrm{Cd}$ concentration was lower than $5 \mathrm{mg} / \mathrm{L}$. Another interesting finding was that NHAP-Cd caused high toxicity to rice seedlings, but did not reduce the plant tissue biomass. Hence, NHAP-Cd and other NPs could be transported to the edible parts of plants such as rice and pose health risk to humans (Du et al., 2011; Rico et al., 2011). In the future, the nanotoxicology of the combined contributions of NPs and toxicants needs to be investigated.

By detecting Cd levels, we found that a higher volume of $\mathrm{Cd}$ was transmitted to the leaves by $\mathrm{NHAP}_{20}-\mathrm{Cd}$ than by $\mathrm{NHAP}_{40}-\mathrm{Cd}$. Our analysis confirmed that the $\mathrm{Cd}$ concentration lower than $5 \mathrm{mg} / \mathrm{L}$ promoted the growth of 'TU-705', which is a Cd-tolerant variety. In the CK, CAT activity increased with an increase in $\mathrm{Cd}^{2+}$ concentration and peaked at $5 \mathrm{mg} / \mathrm{L} \mathrm{Cd}^{2+}$ concentration, whereas reduced at $10 \mathrm{mg} / \mathrm{L} \mathrm{Cd}^{2+}$ concentration. NHAP without $\mathrm{Cd}$ can be toxic to rice seedlings; this finding is similar to that of other studies (Li and Huang, 2014). In the NHAP-Cd treatments, oxidative stress was attributed to Cd and NHAP. The increase of CAT activity indicated lower oxidative stress of NHAP-Cd than $\mathrm{Cd}^{2+}$. Considering the CAT activity of CK as the baseline, that of NHAP-Cd treatment suggested oxidative stress at the Cd concentration lower than $5 \mathrm{mg} / \mathrm{L}$. For the $10 \mathrm{mg} / \mathrm{L} \mathrm{Cd}^{2+}$ addition treatment, CAT activity was in the order of $\mathrm{CK}<\mathrm{NHAP}_{40}-\mathrm{Cd}<\mathrm{NHAP}_{20}-\mathrm{Cd}$, which was caused by the higher toxicity with increasing Cd concentration, while the NHAP content remained unchanged. Moreover, the CAT activity of the
$\mathrm{NHAP}_{20}$-Cd treatment was higher than that of the $\mathrm{NHAP}_{40}$-Cd treatment at all tested $\mathrm{Cd}$ concentrations. The differences in CAT activity between NHAP-Cd treatments and CK suggested that NHAP-Cd has a different toxicity mechanism in rice seedlings. TEM photographs of controlled and tested seedlings suggested that the NPs could enter the cells via channel proteins, plasmodesmata, or endocytosis (Zheng et al., 2009). After the NPs reached the inner side of cells, they could be dissolved by enzymes and released as $\mathrm{Cd}$ ions. Therefore, undissolved NPs and released Cd ions are both toxic to the cells (Kittler et al., 2010).

We cannot completely explain the mechanism of how NHAP$\mathrm{Cd}$ is toxic to plants in this study. In the future, we intend to focus on the Cd transfer under the impacts of NPs. One of the possible mechanisms is that NHAP-Cd particles cling to the root surface and enter the plants. Once the NHAP-Cd particles enter the cells, they can be dissolved by various enzymes. Therefore, NHAP-Cd can cause mechanical damage, resulting in oxidative stress or toxicity to the cell by releasing $\mathrm{Cd}^{2+}$. According to another study, like fullerene $C_{70}$, the NHAP-Cd particles might be transported to the aboveground parts via the phloem (Lin et al., 2009a,b; Liu et al., 2009) at the cellular level, NHAP-Cd particles are assumed to enter the cells through channel proteins, plasmodesmata, and via endocytosis (Conner and Schmid, 2003; Hild et al., 2008; Huang et al., 2010).

\section{Conclusions}

NHAP-Cd can directly pass through the cytoderm into rice seedlings rather than in the form of $\mathrm{Cd}^{2+}$ and can be translocated in rice seedlings via the vascular bundle, resulting in less serious oxidative stress than that caused by $\mathrm{Cd}^{2+}$ to the plants. In addition, $\mathrm{NHAP}_{20}-\mathrm{Cd}$ treatments caused more biomass decrease and root retardation compared to $\mathrm{NHAP}_{40}-\mathrm{Cd}$ treatment. By comparing the $\mathrm{Cd}$ content from different treatments in the mesocotyl, we could conclude that smaller NHAP-Cd can move easily in the rice seedlings. The differences of translocation between $\mathrm{NHAP}_{20}-\mathrm{Cd}$ and $\mathrm{NHAP}_{40}-\mathrm{Cd}$ implied that particle size plays an important role for the toxicity of NPs as an adsorbent to adsorb toxicants. Finally, the potential risks of NPs adsorbed with toxicants should be given more attention because their nanostructure remains unchanged when they are transported to the edible parts of plants.

\section{Funding}

This work was supported by The National Science Foundation of China [grant no., 41273136] and Natural Science Foundation of Tianjin [grant no, 13JCYBJC25400].

\section{References}

Bala, N., Dey, A., Das, S., Basu, R., Nandy, P., 2014. Effect of Hydroxyapatite nanorod on chickpea (Cicer arietinum) plant growth and its possible use as nano-fertilizer. Iran. J. Plant Physiol. 4 (3), 1061-1069.

Barrena, R., Casals, E., Colón, J., Font, X., Sánchez, A., Puntes, V., 2009. Evaluation of the ecotoxicity of model nanoparticles. Chemosphere 75 (7), 850-857.

Bian, R., Chen, D., Liu, X., Cui, L., Li, L., Pan, G., Xie, D., Zheng, J., Zhang, X., Zheng, J., Chang, A., 2013. Biochar soil amendment as a solution to prevent Cd-tainted rice from China: results from a cross-site field experiment. Ecol. Eng. 58, 378-383.

Conner, S.D., Schmid, S.L., 2003. Regulated portals of entry into the cell. Nature 422 (6927), 37-44.

Dietz, K.J., Herth, S., 2011. Plant nanotoxicology. Trends Plant Sci. 16 (11), 582-589.

Du, W., Sun, Y., Ji, R., Zhu, J., Wu, J., Guo, H., 2011. TiO 2 and $\mathrm{ZnO}$ nanoparticles negatively affect wheat growth and soil enzyme activities in agricultural soil. J. Environ. Monit. 13 (4), 822-828.

Fan, W., Cui, M., Liu, H., Wang, C., Shi, Z., Tan, C., Yang, X., 2011. Nano-TiO 2 enhances the toxicity of copper in natural water to Daphnia magna. Environ. Pollut. 159 (3), 729-734. 
Feng, Y., Gong, J.L., Zeng, G.M., Niu, Q.Y., Zhang, H.Y., Niu, C.G., Deng, J.H., Yan, M., 2010. Adsorption of Cd (II) and Zn (II) from aqueous solutions using magnetic hydroxyapatite nanoparticles as adsorbents. Chem. Eng. J. 162 (2), 487-494.

Gaiser, B.K., Fernandes, T.F., Jepson, M., Lead, J.R., Tyler, C.R., Stone, V., 2009. Assessing exposure, uptake and toxicity of silver and cerium dioxide nanoparticles from contaminated environments. Environ. Health 8 (Suppl. 1), S2.

Harper, B., Sinche, F., Ho Wu, R., Gowrishankar, M., Marquart, G., Mackiewicz, M., Harper, S.L., 2014. The impact of surface ligands and synthesis method on the toxicity of glutathione-coated gold nanoparticles. Nanomaterials 4 (2), 355-371

He, Q., Yang, D., Deng, X., Wu, Q., Li, R., Zhai, Y., Zhang, L., 2013. Preparation, characterization and application of N-2-Pyridylsuccinamic acid-functionalized halloysite nanotubes for solid-phase extraction of $\mathrm{Pb}$ (II). Water Res. 47 (12), 3976-3983.

Hild, W.A., Breunig, M., Göpferich, A., 2008. Quantum dots-nano-sized probes for the exploration of cellular and intracellular targeting. Eur. J. Pharm. Biopharm. 68 (2), 153-168.

Hoagland, D.R., Arnon, D.I., 1938. The method for growing plants without soil: water-culture. Circ. Agric. Exp. Station 347, 1-32.

Huang, W., Wang, D., 2007. Preparation of hollow porous HAP microspheres as drug delivery vehicles. J. Wuhan Univ. Technol. Mater. Sci. Ed. 22 (1), 174-177.

Huang, X., Teng, X., Chen, D., Tang, F., He, J., 2010. The effect of the shape of mesoporous silica nanoparticles on cellular uptake and cell function. Biomaterials 31 (3), 438-448.

Jin, Y., Liu, W., Li, X.L., Shen, S.G., Liang, S.X., Liu, C., Shan, L., 2016. Nano-hydroxyapatite immobilized lead and enhanced plant growth of ryegrass in a contaminated soil. Ecol. Eng. 95, 25-29.

Katsnelson, B.A., Degtyareva, T.D., Minigalieva, I.I., Privalova, L.I., Kuzmin, S.V. Yeremenko, O.S., Kireyeva, E.P., Sutunkova, M.P., Valamina, I.I., Khodos, M.Y., Kozitsina, A.N., Shur, V.Y., Vazhenin, V.A., Potapov, A.P., Morozova, M.V., 2011 Subchronic systemic toxicity and bioaccumulation of $\mathrm{Fe}_{3} \mathrm{O}_{4}$ nano-and microparticles following repeated intraperitoneal administration to rats. Int. J. Toxicol. 30 (1), 59-68.

Kittler, S., Greulich, C., Diendorf, J., Koller, M., Epple, M., 2010. Toxicity of silver nanoparticles increases during storage because of slow dissolution under release of silver ions. Chem. Mater. 22 (16), 4548-4554.

Lee, W.M., An, Y.J., Yoon, H., Kweon, H.S., 2008. Toxicity and bioavailability of copper nanoparticles to the terrestrial plants mung bean (Phaseolus radiatus) and wheat (Triticum aestivum): Plant agar test for water-insoluble nanoparticles. Environ. Toxicol. Chem. 27 (9), 1915-1921.

Li, Z., Huang, J., 2014. Effects of nanoparticle hydroxyapatite on growth and antioxidant system in pakchoi (Brassica chinensis L.) from cadmium-contaminated soil. J. Nanomater. 2014.

Li, L., Liu, X., Peijnenburg, W.J., Zhao, J., Chen, X., Yu, J., Wu, H., 2012. Pathways of cadmium fluxes in the root of the halophyte Suaeda salsa. Ecotoxicol. Environ. Saf. 75, 1-7.

Lin, S., Reppert, J., Hu, Q., Hudson, J.S., Reid, M.L., Ratnikova, T.A., Rao, A.M., Lou, H. Ke, P.C., 2009a. Uptake, translocation, and transmission of carbon nanomaterials in rice plants. Small 5 (10), 1128-1132.

Lin, W., Xu, Y., Huang, C.C., Ma, Y., Shannon, K.B., Chen, D.R., Huang, Y.W., 2009b. Toxicity of nano-and micro-sized $\mathrm{ZnO}$ particles in human lung epithelial cells. J. Nanopart. Res. 11 (1), 25-39.

Liu, Q., Chen, B., Wang, Q., Shi, X., Xiao, Z., Lin, J., Fang, X., 2009. Carbon nanotubes as molecular transporters for walled plant cells. Nano Lett. 9 (3), 1007-1010.

Maehly, A.C., Chance, B., 1959. The assay of catalase and peroxidase. In: Glick, D. (Ed.), Methods of Biochemical Analysis, 1. Interscience Publishers, New York, pp. 357-425

Midander, K., Cronholm, P., Karlsson, H.L., Elihn, K., Möller, L., Leygraf, C., Wallinder, I.O., 2009. Surface characteristics, copper release, and toxicity of nano-and micrometer-sized copper and copper (II) oxide particles: a cross-disciplinary study. Small 5 (3), 389-399.
Mobasherpour, I., Salahi, E., Pazouki, M., 2012. Comparative of the removal of $\mathrm{Pb}^{2+}$ $\mathrm{Cd}^{2+}$ and $\mathrm{Ni}^{2+}$ by nano crystallite hydroxyapatite from aqueous solutions: adsorption isotherm study. Arab. J. Chem. 5 (4), 439-446.

Moya, J.L., Ros, R., Picazo, I., 1993. Influence of cadmium and nickel on growth, net photosynthesis and carbohydrate distribution in rice plants. Photosynth. Res. 36 (2), 75-80.

Nie, X., Dong, F., Liu, N., Liu, M., Zhang, W., Sun, S., Yang, J., 2014. An investigation on the subcellular distribution and compartmentalization of uranium in Phaseolus vulgaris L. J. Radioanal. Nucl. Chem. 299 (3), 1351-1357.

Rezvanfar, M.A., Rezvanfar, M.A., Shahverdi, A.R., Ahmadi, A., Baeeri, M. Mohammadirad, A., Abdollahi, M., 2013. Protection of cisplatin-induced spermatotoxicity, DNA damage and chromatin abnormality by selenium nano-particles. Toxicol. Appl. Pharmacol. 266 (3), 356-365

Rico, C.M., Majumdar, S., Duarte-Gardea, M., Peralta-Videa, J.R., Gardea-Torresdey, J.L., 2011. Interaction of nanoparticles with edible plants and their possible implications in the food chain. J. Agric. Food Chem. 59 (8), 3485-3498.

Roh, J.Y., Sim, S.J., Yi, J., Park, K., Chung, K.H., Ryu, D.Y., Choi, J., 2009. Ecotoxicity of silver nanoparticles on the soil nematode Caenorhabditis elegans using functional ecotoxicogenomics. Environ. Sci. Technol. 43 (10), 3933-3940.

Rong, Z.J., Yang, L.J., Cai, B.T., Zhu, L.X., Cao, Y.L., Wu, G.F., Zhang, Z.J., 2016. Porous nano-hydroxyapatite/collagen scaffold containing drug-loaded ADM-PLGA microspheres for bone cancer treatment. J. Mater. Sci. Mater. Med. 27 (5), 1-12

Shah, V., Belozerova, I., 2009. Influence of metal nanoparticles on the soil microbial community and germination of lettuce seeds. Water Air Soil Pollut. 197 (1-4), $143-148$

Shah, K., Kumar, R.G., Verma, S., Dubey, R.S., 2001. Effect of cadmium on lipid peroxidation, superoxide anion generation and activities of antioxidant enzymes in growing rice seedlings. Plant Sci. 161 (6), 1135-1144.

Shaw, A.K., Hossain, Z., 2013. Impact of nano-CuO stress on rice (Oryza sativa L.) seedlings. Chemosphere 93 (6), 906-915.

Stone, V., Donaldson, K., 2006. Nanotoxicology: signs of stress. Nat. Nanotechnol. 1 (1), 23-24.

Tateoka, T., 1969. Notes on some grasses: XX. Systematic significance of the vascular bundle system in the mesocotyl. Jpn. J. plant Sci. 82, 387-391.

Trujillo-Reyes, J., Majumdar, S., Botez, C.E., Peralta-Videa, J.R., Gardea-Torresdey, J.L., 2014. Exposure studies of core-shell $\mathrm{Fe} / \mathrm{Fe}_{3} \mathrm{O}_{4}$ and $\mathrm{Cu} / \mathrm{CuO}$ NPs to lettuce (Lactuca sativa) plants: are they a potential physiological and nutritional hazard? J. Hazard. Mater. 267, 255-263.

Usenko, C.Y., Harper, S.L., Tanguay, R.L., 2007. In vivo evaluation of carbon fullerene toxicity using embryonic zebrafish. Carbon 45 (9), 1891-1898.

Wang, H., Wick, R.L., Xing, B., 2009. Toxicity of nanoparticulate and bulk ZnO, $\mathrm{Al}_{2} \mathrm{O}_{3}$ and $\mathrm{TiO}_{2}$ to the nematode Caenorhabditis elegans. Environ. Pollut. 157 (4), 1171-1177.

Wang, D., Hu, J., Forthaus, B.E., Wang, J., 2011. Synergistic toxic effect of nano- $\mathrm{Al}_{2} \mathrm{O}_{3}$ and As (V) on Ceriodaphnia dubia. Environ. Pollut. 159 (10), 3003-3008.

Wang, S., Liu, H., Liu, W., Zuo, O., 2016. Effect of low-molecular-weight organic acids on nano-hydroxyapatite adsorption of cadmium and lead. J. Biomater Tissue Eng. 6 (6), 433-439.

Zeng, F., Zhou, W., Qiu, B., Ali, S., Wu, F., Zhang G, 2011. Subcellular distribution and chemical forms of chromium in rice plants suffering from different levels of chromium toxicity. J. Plant Nutrit. Soil Sci. 174 (2), 249-256.

Zhang, Z., Li, M., Chen, W., Zhu, S., Liu, N., Zhu, L., 2010. Immobilization of lead and cadmium from aqueous solution and contaminated sediment using nano-hydroxyapatite. Environ. Pollut. 158 (2), 514-519.

Zheng, S., Li, J., Lykotrafitis, G., Bao, G., Suresh, S., 2009. Size-dependent endocytosis of nanoparticles. Adv. Mater. 21 (4), 419-424. 